\title{
Prevalence of Fungi Associated with Rice Leaf Spot in the Main Rice-Growing Areas in Paraguay
}

\author{
${ }^{1}$ Lidia Quintana, ${ }^{2}$ Susana Gutiérrez, ${ }^{1}$ Aldo Ortiz \\ ${ }^{1}$ Laboratorio de Fitopatología, Departamento de Investigación y Extensión, Facultad de Ciencias Agropecuarias y Forestales, Universidad Nacional de Itapúa, \\ Encarnación, Itapúa, Paraguay. \\ ${ }^{2}$ Cátedra de Fitopatología, Facultad de Ciencias Agrarias, Universidad Nacional del Nordeste, Corrientes, Argentina.
}

Correspondence Author: Lidia Quintana, Laboratorio de Fitopatología, Departamento de Investigación y Extensión, Facultad de Ciencias Agropecuarias y Forestales, Universidad Nacional de Itapúa, Encarnación, Itapúa, Paraguay.

E-mail:- lviedmaq@gmail.com

Received date: 15 June 2019, Accepted date: 21 August 2019, Online date: 29 August 2019

Copyright: ( 2019 Lidia Quintana et al, This is an open-access article distributed under the terms of the Creative Commons Attribution License, which permits unrestricted use, distribution, and reproduction in any medium, provided the original author and source are credited.

\begin{abstract}
The extensive monoculture of improved rice varieties, together with more intensive management practices in the last decade, has increased crop yields but also increased the severity of rice diseases in Paraguay. Due to scarce national information on this topic, a research work was carried out at the Plant Pathology Laboratory of the Faculty of Agricultural Sciences at University of Itapúa. The objective of this study was to determine the prevalence of fungal species associated with rice leaf spot on the main rice-growing area of the country in the years 2016 and 2017. Samples of rice plants with symptoms of leaf spots were collected from commercial fields of Itapúa, Misiones, Caazapá and Ñeembucú departments and examined under a stereoscope and subsequently isolated in Potato Dextrosa Agar culture media during 10 days to obtain a pure culture. For identification of fungal species, taxonomic keys and disease identification manuals were used. Morphological structures of fungus were performed using stereoscopic and optical microscopy $(400 x)$ and each leaf sample was considered to be infected with the presence of the fructification structures of the fungi. Six fungal species associated with symptoms of rice leaves spot were identified in this research work: Alternaria padwickii, Bipolaris oryzae Microdochium oryzae, Curvularia spp, Pyricularia oryzae and Cercospora janseana. In both years, 2016 and 2017 B. oryzae showed the highest average mean incidence. A. padwickii was the most prevalent fungus in Itapúa department in the year 2016 and B. oryzae at Ñeembucú department in 2017.
\end{abstract}

Keywords: Oryza sativa, leaf rice diseases, fungi, incidence

\section{INTRODUCTION}

Rice in Paraguay is grown mainly in the Departments of Misiones, Itapúa, Caazapá, and Neembucú and to a lesser extent in Paraguarí, Concepción, San Pedro, lower Chaco and other Departments with an approximate production of 900.000 tons on the $2017 / 2018$ cycle. Through the use of more productive varieties, and the adoption of technologies production, such as the use of fertilizers and agrochemicals for the control of pests, diseases and weeds, rice yields could have reached up to 9 ton/ha, however, the national average does not exceed 4 ton/ha (INBIO 2018).

Webster \& Gunnell (1992) reported that rice crop is affected by numerous infectious agents from germination to physiological maturity, causing different diseases. Some of these diseases are a potential risk because of their impact on yield and quality of production. Among the diseases of fungal origin that produce rice leaf spots are the brown spot (Bipolaris oryzae), the narrow spot (Cercospora janseana), scald (Microdochium oryzae), rice leaf blight or blast (Pyricularia oryzae), alternaria spot (Alternaria padwickii, syn. Trichoconiella padwickii). These was later confirmed by Mew \& Gonzales (2002) on rice seed-borne fungi.

Sesma \& Osbourn (2004) stated that rice blast is a very destructive disease affecting rice production, it is widely distributed throughout the world, and can lead to a severe loss of yield of up to 50\%. Similar results were reported by Cardenas et al. (2010). Lovato et al. (2013) in their study on T. padwickii seed transmission to rice coleoptiles indicate that the fungus, in addition to causing foliar spot, can also affect the grains of the rice panicle, affecting the quality and the germination when sowing the infected seeds. 
Citation: Lidia Quintana, et al., Prevalence of Fungi Associated with Leaf Rice Spot in the Main Rice- Growing Areas in Paraguay. Australian Journal of Basic and Applied Sciences, 13(8): 60-63. DOI: 10.22587/ajbas.2019.13.8.9

(Barnwal et al. (2013) in their studies on brown spot or Helminthosporium leaf blight indicated that the disease is becoming a serious threat to rice production causing serious epidemics with loss of yield and quality. Boka et al. (2018) reported yield losses vary widely from 4 to $52 \%$.

Rice scald is also one of the major diseases affecting rice crops worldwide. Hernandez et al. (2016) reported that the disease has the potential to significantly reduce the rice yields through the destruction of leaf surface area and seed decay. Filippi and Prabhu (2005) cited by Araujo et al. (2015) mentioned yield loss due to rice scald of up to $30 \%$.

In the last decade, the extensive monoculture of improved rice varieties used in Paraguay, together with new more intensive management practices, have increased yields, but also increased the severity of some diseases. This statement was investigated by Quintana et al. 2016 a; 2016 b; 2016 c; 2017 and 2018. The hypothesis of this research was that fungal species could be identified by sampling fields with leaf rice spot symptoms from all rice production regions. Based on this a disease survey was conducted throughout the growing season of years 2016 and 2017. Therefore, the objectives of the research work were to determine the incidence of fungal species during the years 2016 and 2017 and the prevalence of fungal species associated with rice leaf spot in the main rice growing-areas in Paraguay.

\section{MATERIALS AND METHODS}

Sample collection: Diseased rice plants samples of the 2016 and 2017 harvest were collected from commercial rice fields of paraguayan departments: Misiones, Itapúa, Ñeembucú and Caazapá. A total of 150 samples were used.

Isolation and purification: Small pieces of infected leaves were placed on three filter paper discs moistened with distilled water in Petri dishes and incubated for 10 days at $30^{\circ} \mathrm{C}, 12 / 12$ hours of light and darkness. Five pieces of 5 replicates of diseased tissue were used for each dish. Samples were examined under a stereoscope and subsequently isolated in Potato Dextrosa Agar culture media for 10 days to obtain a pure culture (French \& Hebert, 1980).

Identification of the fungus: For the identification of fungal species, taxonomic keys and disease identification manuals were used (Mew \& Gonzalez, 2002, Mathur \& Konsgdal, 2003). The identification of pathogen was performed using stereoscopic and optical microscopy $(400 \mathrm{x})$. The sample was considered to be infected with the presence of the fructification structures of fungi (mycelium, conidia, conidiophores, sclerotia, sporodoquium).

Incidence evaluation: The incidence of fungi was calculated by counting the presence of reproductive structures of each species with the help of the stereoscope. The incidence formula used was I = Number of samples with fungal colonies $\mathrm{x} 100 /$ total of samples and was expressed as a percentage.

Statistical analysis: The data were subjected to analysis of variance using the statistical package INFOSTAT Version 1.4 (Di Rienzo et al. 2018). The Tukey test was used for the mean average ( $p<=0.05)$

\section{RESULTS AND DISCUSSION}

\section{Incidence of fungal species on rice leaf samples}

Among the fungal species associated with rice leaf spots, the following were identified: Alternaria padwickii, Bipolaris oryzae, Microdochium oryzae, Pyricularia oryzae, Curvularia spp and Cercospora janseana (Table 1).

Table 1: Average mean incidence and disease name of different fungal species ${ }^{1}$ on rice leaves samples

\begin{tabular}{|c|c|c|}
\hline Fungal species & $\begin{array}{c}\text { Incidence average }^{2}(\%) \\
2016 / 2017\end{array}$ & Disease name \\
\hline $\begin{array}{c}\text { Bipolaris oryzae (Breda de Haan) } \\
\text { Shoemacker }\end{array}$ & $68.7 \mathrm{~A}$ & Brown spot \\
\hline Alternaria padwickii Ganguly M.B. Ellis & $47.2 \mathrm{AB}$ & Alternaria leaf spot \\
\hline Microdochium oryzae Hashioka and Yokogi & $31,2 \mathrm{C}$ & Leaf scald \\
\hline Curvularia spp & $21.3 \mathrm{CD}$ & Curvularia leaf spot \\
\hline Pyricularia oryzae Cav. & $1,50 \mathrm{E}$ & $\begin{array}{c}\text { Rice leaf blight or } \\
\text { blast }\end{array}$ \\
\hline Cercospora janseana Miyake & $0,50 \mathrm{E}$ & Narrow leaf spot \\
\hline
\end{tabular}

${ }^{\mathrm{T}}$ Fungi are designated by the Latin binomial of the anamorph, more frequent in world literature. ${ }^{2}$ Different letters indicate significant differences $(\mathrm{p}<=0.05)$

The statistical analysis indicates significant differences in mean average of fungal incidence associated with samples of rice leaf spot (table 1). B. oryzae showed the highest mean average incidence in the years 2016 and 2017. At the same time, it can be mentioned that the incidence of $M$. oryzae and Curvularia spp, although moderate, remained constant in both years in all monitored departments. Incidence of $P$. oryzae and $C$. janseana was very low. Similar results were obtained in the northeast of Argentina by Gutiérrez et al. (2002) and Lovato et al. (2013a) who reported that A. padwickii was one of the most frequent species on rice leaf spot and seedling diseases. Quintana et al. (2016b) in a survey on rice leaf spot carried out in 2015 season, out of 200 
Citation: Lidia Quintana, et al., Prevalence of Fungi Associated with Leaf Rice Spot in the Main Rice- Growing Areas in Paraguay. Australian Journal of Basic and Applied Sciences, 13(8): 60-63. DOI: 10.22587/ajbas.2019.13.8.9

samples from Itapúa, Misiones and Caazapá departments, indicates that B. oryzae represented 49\% and A. padwickii 40\%,. Those results coincide with our findings.

Viedma, (2010) conducted a rice seed health testing in Paraguay and as results were identified B. oryzae and A. padwickii, being the latter the fungus with higher incidence value (19\%). This situation confirms the importance of the seed as rice leaf spots source of inoculum.

\section{Prevalence of fungal species in 2016 and 2017 harvest}

In both years, the prevalence of $A$. padwickii and B. oryzae was highlighted in all monitored departments. However, in 2016 A. padwickii was the most prevalent fungus in Itapúa department and B. oryzae at Neembucú department in 2017 year (fig. 1). Information from southern brazilian rice-growing regions revealed high prevalence and incidence levels of $B$. oryzae (Farias et al. 2005, Farias et al. 2001) which is similar to our findings.

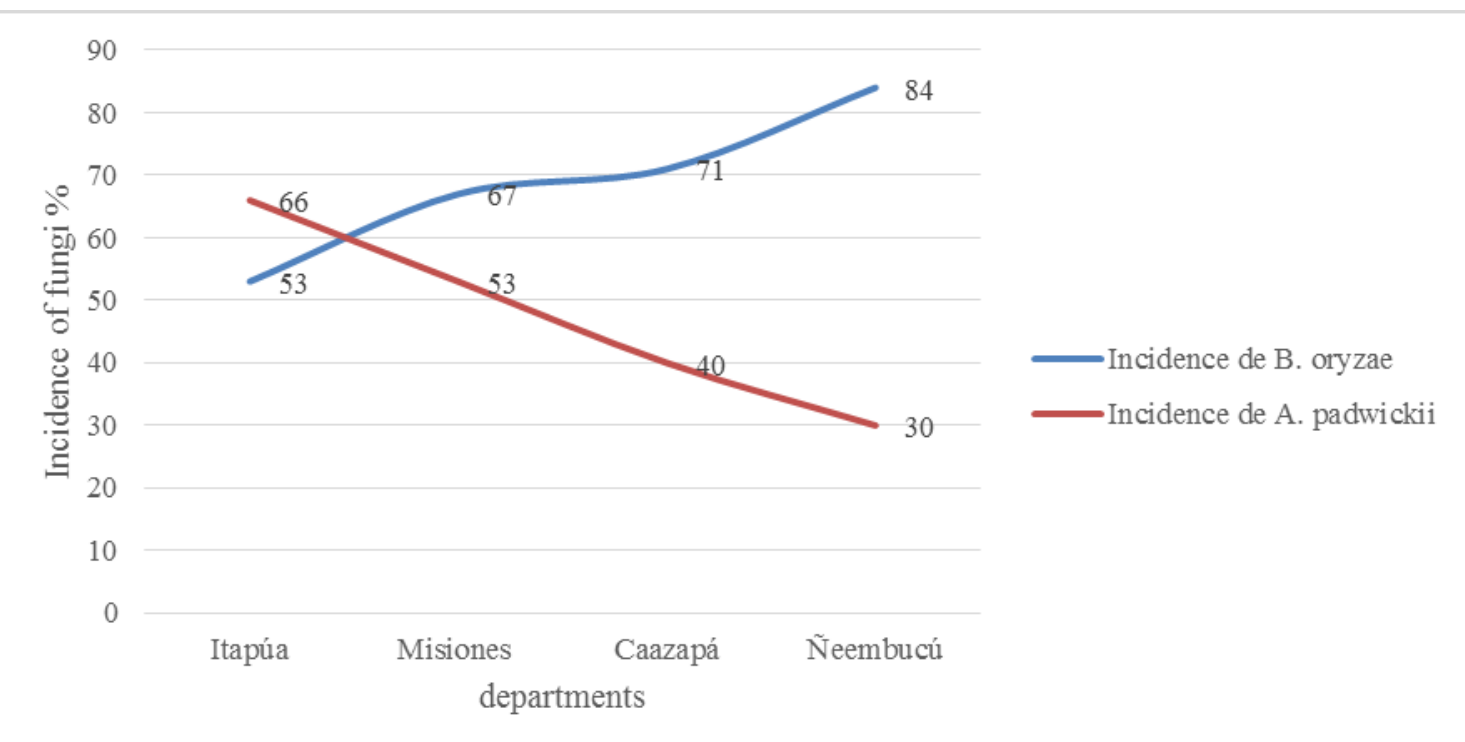

Fig.1. Prevalence of $A$. padwickii and B. oryzae on main rice-growing areas in Paraguay

\section{CONCLUSIONS}

Bipolaris oryzae presents the highest average mean incidence associated with rice leaf spot in both 2016 and 2017 years in main rice growing-areas in Paraguay; while A. padwickii was the most prevalent fungus in Itapúa department in the year 2016 and B. oryzae in Neembucú department in the year 2017 respectively.

\section{ACKNOWLEDGMENT}

The authors thank PROCIENCIA CONACYT for financing this research work

\section{REFERENCES}

Araujo, L., Silva, R., Paschoalino, F., Avila Rodrigues, F. 2015. Microscopic Aspects of Silicon-Mediated Rice Resistance to Leaf Scald. Phytopathology, 2016 106(2): 132-142.

Barnwal, MK., Kotasthane, A., Magculia, N., Mukherjee, PK., Savary, S., Sharma, AK., Singh, HB., Singh, US., Sparks AH., Variar, M., \& Zaidi, N. 2013. A review on crop losses, epidemiology and disease management of rice brown spot to identify research priorities and knowledge gaps. European Journal of Plant Pathology 136 (3):443-457.

Boka, A., A. Bouet, A. Tiendrebeogo, AI. Kassankogno, I. Quedraogo, GNE. Nda, Odette D. Denezon, \&A. Adiko. 2019. Pathogenic variability of Bipolaris oryzae causing leaf spot disease of rice in west Africa. Int. J. Phytopathol. 7 (3):103-110.

Cárdenas, R. M., Mesa, S., Polón, R., Pérez, N., Cristo, E., Fabré, L., Hernández, J. J. 2010. Relación entre la incidencia de la piriculariosis (Pyricularia grisea Sacc.) del arroz (Oryza sativa Lin.) y diferentes variables climáticas en el complejo agroindustrial arrocero Los palacios. Cultivos Tropicales, 31 (1): 14-18.

Di Rienzo JA.,MG. Casanoves, L.Balzarini, M. Gonzalez, M. Tablada \&CW. Robledo. 2018. Grupo InfoStat, FCA, Universidad Nacional de Córdoba, Argentina. http://www.infostat.com.ar. May 2019.

Farias, CRJ., Afonso A., Pierobom, CR \& Ponte EMD. 2011. Regional survey and identification of Bipolarisspp associated with rice seeds in Rio Grande do Sul State, Brazil. Ciencia Rura 141:369-372.

French, ET., Herbert, T. 1980. Métodos de investigación fitopatológica. IICA/CATIE 289 p.

Gutiérrez, SA., MA. Cùndom, .G., Cabrera, AD. Lovato. 2010. Enfermedades foliares del cultivo del arroz. In: XVII Reunión de Comunicaciones Científicas y Técnicas, Corrientes http://www.unne.edu.ar/unnevieja/investigacion/com2010/CAWeb/wCA005_005.pdf. 
Hernandez, M., Restrepol, JZ.,Groenewald, PW., Crous, M. 2016.Persoonia, 36:57-82.

Filippi, M. C. C., and Prabhu, A. S. 2005. Escaldadura do arroz e seu controle. Circular Técnica 72. Embrapa Arroz e Feijao, Santo Antonio de Goias, GO.

INBIO (Instituto de Biotecnología Agrícola). 2017. Estimación de la superficie, rendimiento y producción de cultivos de verano 2017/2018 y otros. Disponible en: http://www.inbio.org.py/biblioteca/estimacion_de_superficies

Lovato Echeverria, AD., SA. Gutiérrez., 2013a. Incidencia de Alternaria padwickii (Ganguly) en semillas de arroz. In: XVIII Reunión de Comunicaciones Científicas y Tecnológicas. 27

LovatoEcheverria, AD., MA.Carmona, SA.Gutiérrez. 2013b.Transmisión de Trichoconiella padwickii a coleóptilos de arroz.Trop. PlantPathol. 38(4):346-348.

Mathur, S.B., O.Konsgdal.2003. Common laboratory seed health testing for detecting fungi..Seed Pathology Institute, Copenhaguen, Denmark.

Mew, TW.,P. Gonzales. 2002. A handbook of rice seed-borne fungi. Los Baños, IRRI, Philippines 83p.

Quintana,L., SA. Gutiérrez, M. Arriola, K.Morínigo. 2016a. Detección de Alternariapadwickiien el cultivo de arroz en principales zonas de producción. Summa Phytopathologica Vol. 42 (supplement).

Quintana,L.,Gutiérrez, SA., Arriola, M., K.Morínigo. 2016b. Prevalencia de Alternariapadwickiien el cultivo de arroz en principales zonas de producción. SummaPhytopathologica Vol. 42 (supplement).

Quintana, L., S. Gutiérrez, M Arriola, M. Maidana. 2016c. Incidencia de patógenos causantes de manchas foliares de arroz en Paraguay. Revista del Saber Académico y del Conocimiento, Año 10-No 10, p: 103-106.

Quintana, L., Gutiérrez, S., Arriola, M., Ortiz. 2017. Rice brown spot (Bipolaris oryzae (Breda de Haan) Shoemaker in Paraguay. Tropical Plant Research 4(3): 419-420, 2017.

Quintana, L., S. Gutiérrez, A. Ortiz. 2018. Microdochium oryzae associated with rice leaf scald in Paraguay. Australian Journal of Basic and Applied Sciences 12(7):56-58.

Sesma A., AE. Osbourn. 2004. The rice leaf blast pathogen undergoes developmental processes typical of root-infecting fungi. Nature 431:582-586.

Viedma, L. 2010. Evaluación de la sanidad de semilla de arroz (Oryza sativa) en Paraguay. Revista sobre Estudios e Investigaciones del Saber Académico. Universidad Nacional de Itapúa. 4(4):17-24.

Webster, R., PS. Gunnell.eds. 1992. Compendium of Rice Diseases. St. Paul, MN. APS.92 p. 